ACTA UNIVERSITATIS LODZIENSIS

FOLIA LITTERARIA POLONICA 7(45) 2017

http://dx.doi.org/10.18778/1505-9057.45.08

Józef Maria Ruszar*

\title{
Freedom and possession in the letters of Andrzej Bobkowski
}

The title of my study, which utilises the pungent vocabulary of the author of Szkice piórkiem, uses the so-called male manner to refer to the existential issue which was fundamental for Bobkowski, i.e. one's retention of one's freedom founded on material independence, and achieved through one's own work. In one of his letters, he noted: "At any time of the day I can look into a mirror [...] and say: you haven't become a fuck-up one bit." Which constitutes a statement, a life's motto, and an economic programme all in one. As a result, the writer's idea fixe consisted of a change from the status of a political emigre to the situation of an economic migrant, or at least that was the conclusion drawn by Andrzej Stanisław Kowalczyk ${ }^{2}$, against which one cannot argue with the reservation that it does not mean in any way that he lost his right or even his duty to remain politically engaged in the struggle for Poland's freedom.

Any arrangements with communism or any other totalitarian system were out of the question, though the allowed methods of writers' influence on readers in the captive Poland evolved in the writer's mind, and in the 1940s, Bobkowski published in the Tygodnik Powszechny weekly and in other domestic periodicals, but he did not publish after the introduction of Socialist realism. Also the existence of censorship after the so-called thaw of 1956 was the reason why Bobkowski did not agree for domestic reprints, which, actually, was the cause of his conflict with Giedroyc as Maison-Laffitte was of the opinion that any opportunity to cross the Iron Curtain was beneficial to the struggle to break the communist monopoly in Poland. Interestingly enough, in his argument, the writer emphasised not only the

* Dr, e-mail: jozef.ruszar@ignatianum.edu.pl; Department of Media and Communication, Faculty of Philosophy, Jesuit University Ignatianum in Krakow, 31-501 Krakow, 26 Kopernika street.

${ }^{1}$ A fragment of a letter to W. Jekiel dated 10 Dec 1948, a representative of the Contemporary Literature Club (Klub Literatury Współczesnej) established by the students of Polish studies at the University of Warsaw (as cited in "Wstęp" by A.S. Kowalczyk to: Andrzej Bobkowski - Aniela Mieczysławska. Listy 1951-1961, Biblioteka „Więzi”, Warsaw 2010, p. 19). [English version translated from Polish].

2 Ibid., p. 19. 
political subjugation due to the fact of becoming dependant on the decisions of the communist authorities, but also the attempt at, on the one hand, making emigre writers dependent economically, and, on the other, exerting financial pressure on them. That mode of thinking in which freedom was closely related to its economic guarantees understood as financial independence was probably the most distinctive mental characteristic of Bobkowski. I shall attempt to trace it using several examples.

\section{Against the concept of Romantic emigration}

The status of a writer, which defines his particular situation, must be the first basic ascertainment or a starting point for a discussion. Such a starting point in the case of Bobkowski was the fact of his being an emigre, and an emigre writer. Contrary to what they may seem, those terms are not clear, and must be made more precise as, apparently, the author of Szkice piórkiem himself made the issue both more precise and complicated.

The notion of a "Cosmopole" (Kosmopolak) proposed by Bobkowski, and its divergence from the classic role of emigration, has been discussed thoroughly in professional literature, so only to recapitulate let me state that it creates a somewhat ironic situation because formally the so-called soldier emigration after WWII was dominated by the notion of steadfast political emigration, yet in practice it was impossible to fulfil it. Thousands of former Polish Armed Forces soldiers in the West were forced to become economic migrants because after a very short period of hope for WWIII, to maintain any military units in battle-ready condition was out of the question.

Therefore, against the statement that the essence of political emigration was the active disputing of the post-WWII status quo, life forced assimilation in the country of emigration, not an existence rooted in a future of a dreamt up motherland which in some way, e.g. through an armed confrontation between the West and the East, would regain independence. A missionary life could only be indulged in by very few people, more precisely: creative individuals, i.e. writers, journalists in emigre journals, the few people engaged in cultural projects, and a small group of professional politicians gathered in emigre organisations or around the Government of the Republic of Poland in exile. The rest could only fulfil the political or material support function for the emigration elite. Thus, the dispute between Bobkowski and the dominant emigration ideology only applied to the mode of existence of that elite, not the emigrants en masse as most of them - like the author of $Z$ dziennika podróży - took up work in the countries of emigration. 
But Bobkowski was a writer, and his concept applied to the mode of life of an emigration artist or intellectual. At the same time, Tymon Terlecki, whose opinion could be considered as binding, wrote that "emigration is essentially [...] Romantic, idealistic. Emigration reaches outside the existing reality, and aspires to another reality." 3 Such a split reality, where at the level of a political evaluation of the situation it was absolutely justified, could not possibly be accepted by Bobkowski at the level of his personal life's strategy as he believed that only the personal achievements of a Cosmopole, i.e. a Pole who grew into the community to which he emigrated, would matter for the evaluation of an individual accomplished life, but it would also strengthen the political power of emigration as a whole.

However, both the concept and the perfect notion of life stemmed not only from his "anarchistic inclinations" and "life's grit" views, but also from a certain vision of freedom which according to Bobkowski was an illusion or self-deception if it was not founded in economic independence. Material security guaranteed freedom, as well as autonomy from the favour of English-American allies, which I shall discuss later on. In that sense, the Cosmopole was a citizen of the world who did not become a burden for the country of emigration but a valuable citizen, and if, additionally, he was a talented individual, e.g. an artist, then - like Chopin or Conrad - he could support the so-called Polish cause with his success because, paradoxically, the fact of placing "universal issues" and not "the Polish cause" in the forefront, gave a Polish emigre artist an opportunity to become successful, or even to have some influence on public opinion. ${ }^{4}$

Considering the fact that the term Cosmopole is not always understood based on its entire content, it is worth noting that when Bobkowski defined himself, and summed up his achievements towards to the end of his life, he also stressed his influence on the indigenous people:

Therefore, per saldo, this is, per saldo, a very happy Man writing to you. I even sometimes get to feel like Sobieski at Vienna. I handled everything, I built a new life out of nothing here, a free life, full of freedom, I acquired people's respect, I have already raised an entire crowd of young people for whom the notion of "Polish community" is not a set of empty sounds. They learnt about it through me as much as it was possible. Somewhere, some time, it might come in handy. ${ }^{5}$

\footnotetext{
${ }^{3}$ T. Terlecki, "Emigracja walki”, Wiadomości 1946, issue 2, as cited in: A.S. Kowalczyk, "Wstęp", p. 19.

${ }^{4}$ That concept was presented emphatically in an article entitled "Biografia wielkiego Kosmopolaka", Kultura 1960, issue 9/155; http://static.kulturaparyska.com/attachments/cb/b0/4389fdd1e f03ab9dd13faf07db8cccde93451e83.pdf\#page=11 (accessed on 28.11.2015).

${ }^{5}$ A. Bobkowski, Listy do Jerzego Turowicza 1947-1960, M. Urbanowski (ed.), Biblioteka „Więzi”, Warsaw 2013, p. 112. [English version translated from Polish].
} 
The fact that those words were written by a person facing impending and expected death was important. It is also noteworthy that the letter was addressed to Jerzy Turowicz, at that time editor-in-chief of Tygodnik Powszechny, while some expressions resembled the famous confession of St. Paul, which begins with: "I have fought the good fight, I have finished the race, I have kept the faith" (2 Timothy 4:7; Holy Bible, New International Version ${ }^{\circledR}$, NIV $^{\circledR}$ Copyright $(1973$, 1978, 1984, 2011 by Biblica, Inc.)

At this point it is worth noting that both the explicite expressed opinions as the provided examples of the implemented attitude of the Cosmopole (Conrad as a particular model) emphasise not only economic independence but also its ingraining in the world in which he lived in exile. Bobkowski believed that Terlecki's formulation, with which he entered into a polemic, was a schizophrenic model, which also remained in conflict with life, thus being demoralising. ${ }^{6}$ No wonder, then, that in his letters to Giedroyc, and to other addressees, he so often described the process of his growing into the local community: "I am growing roots here, a thousand problems essential to me, philistine in nature, seem to you [...] meaningless [...] But I, [...] despite everything, am trying to return myself to that NORMAL LIFE, which throughout the years I managed to forget $[\ldots]$...'?

As I have already mentioned, that opposition is not obvious, and I will have to return to it at some point because a thus understood normality/emigration opposition did not apply, of course, to the crowds of former soldiers of the Polish II Corps, and other Polish armed units. Those soldiers usually acted similarly to Bobkowski, i.e. adjusted to living in England or the United States by going to work or establishing their own little business ventures, or even big companies. If Bobkowski's situation was slightly different, it was because in Guatemala he struggled alone for his existence, away from any communities of emigres. Therefore, the objection towards anti-normality basically applied to so to speak - "professional emigres", about whom in the quoted letter he stated that they lived in an atmosphere of "eternal uncertainty", like the members of a "travelling circus troupe."

${ }^{6}$ The argument about the demoralising aspect of thus understood notion of emigration, and Bobkowski's opposition towards two realities were indicated by A.S. Kowalczyk (idem, "Wstęp", p. 20.).

7 J. Giedroyc, A. Bobkowski, Listy 1946-1961, Czytelnik, Warsaw 1997, Letter 63.

${ }^{8}$ Ibid. 


\section{Being an independent writer}

The concept of a Cosmopole's identity was influenced by another vision of one's independence as a writer. And even though those two notions cannot be divided completely, for the sake of the clarity of the study they must be discussed separately. Bobkowski valued those writers who drew the material for their works from the so-called life, i.e. their personal experience. Not accidentally Conrad was for him an icon of grand literature and a perfect model, obviously not in the sense of some direct influence he exerted on Bobkowski's works, but due to his weaving the fabric of his novels based on personal experiences, and professional knowledge. ${ }^{9}$ Therefore, Conrad's works were not some stylistic ventures but a study of a deliberate existence. Bobkowski offered a very similar summary of his views in a letter to his mother Stanisława Bobkowska: "Too much is happening right now, there is too much emphasis on non-thinking only to toy with form. And yet people desire thoughts - kind and warm.." ${ }^{10}$ A characteristic feature of his works, as well as his views on them, was the obligation on contemporary writers to possess expertise. ${ }^{11}$

In fact, Bobkowski clearly possessed a documentary talent, and it is no wonder that his greatest literary achievements included two journal volumes (Szkice piórkiem and $Z$ dziennika podróży), and letters. Both constitute transitional or hybrid forms, difficult to classify in terms of their genre because both the letters and the records of the author of $Z$ dziennika modelarza are, essentially, a combination of a report and an essay, regardless of any genre classification. One could assume that had Bobkowski become a journalist, he would had occupied a place somewhere between Wańkowicz and Kapuściński. The talent of the writer/documentalist was not developed further because he did not decide to pursue it professionally, and remained an amateur writer who preferred other sources of income.

That decision stemmed both from his lack of confidence in his novelistic talent, and his fear of losing his independence. He feared financial dependency, not entirely without reason. Both his intellectual independence, and his pamphlet style (visible mainly in his letters) clearly indicate that he would have had a seri-

${ }^{9}$ Only the stories in Coco de Oro indicate his inspiration from Conrad. It is absent from Bobkowski's greatest achievements, i.e. documentary forms, stemming from journalist and diaristic literature: Szkice piórkiem, and from Z dziennika podróży.

${ }^{10}$ From a letter of 29 June 1947, I am quoting after "Wstęp" by A.S. Kowalczyk to: Andrzej Bobkowski-Aniela Mieczystawska..., p. 34 (the quoted letter can be found in the Archive of the MaisonsLaffitte Literary Institute, and it was not included in the collection of letters he exchanged with his mother: A. Bobkowski, Listy z Gwatemali do matki, E. Jurczyszyn (ed.), Twój Styl, Warsaw 2008).

${ }^{11}$ A. Bobkowski, Listy do Jerzego Turowicza 1947-1960, M. Urbanowski (ed.), Biblioteka „Więzi”, Warsaw 2013, pp. 59-61. 
ous problem with emigre readers - much bigger than the previously-mentioned Melchior Wańkowicz, who was highly praised for his grand report on the Battle of Monte Cassino, and, in turn, the more violently rejected due to his collection of essays and columns entitled Kundlizm. Bobkowski's controversial articles published in Kultura, and his critical attitude towards certain manifestations of emigre life seemed to indicate that his biting remarks caused him many enemies. Finally, one more argument, rather fundamental, I must add, one against taking up a job as a journalist and a reporter: too small publishing market. The few and economically feeble Polish emigre periodicals were not encouraging for engaging in this profession.

The infrequent nature of his writings was a price for not being subjected to community censorship, and the favour of cultural and political foundations. Such an attitude was absolutely incomprehensible for someone who valued the author's works, and wanted to offer him appropriate conditions for his creative work. ${ }^{12}$ Unfortunately, the letters of Aniela Mieczysławska have not survived, and we only possess the argumentation of Bobkowski, though it clearly shows that he had to fight the community that admired him, and who desperately wanted to delight him with creative grants. In fact, his acquaintance with Mieczysławska began with the New York emigration activist trying to, at Giedroyc's request, shove the scholarship of an American foundation down the writers throat, and him opposing it firmly. Let us leave for a moment the issue of Bobkowski's strategy as an employee, for whom such a type of aid would distort his careful plan of creating his own little business with model planes, as that is another matter. Let us focus on the freedom-themed rhetoric of the author of $Z$ dziennika modelarza:

When I decided to leave Europe, some of the major reasons which drove me to it were the urge to sever myself from exactly that constant living off such funding, from the funding hopscotch, which was surely lurking around me [...] sitting on

${ }^{12}$ In my most recent letter, as well as in earlier ones, I indicated that I did not want any help. Maybe they did not understand me, either way two months ago I stated that categorically. I am afraid, though, that they, driven only by great amity towards me, and maybe somewhat alarmed by some indications of neurasthenia on my part, decided to nonetheless rescue and violate me. But that is absolutely impossible. I do not want any help now, and if I was ever given it, I would never be able to accept it. I hope that you, a woman, i.e. a grounded being and not someone with their head in the clouds, will understand my intentions. When I decided to leave Europe, some of the major reasons which drove me to it were the urge to sever myself from exactly that constant living off such funding, from the funding hopscotch, which was surely lurking around me because they would simply not let me leave for some job (I may be flattering myself but that is what I think) where I would had wasted my talent and opportunities. I am not overestimating my talent. There is certainly something inside me, and I feel that I possess literary capabilities. I am simply stating that without the contortions of false modesty. Despite that, I do not enjoy sitting on funding, and I perceive it as a form of constraint (Andrzej Bobkowski-Aniela Mieczysławska ..., pp. 39-40). 
funding, and I perceive it as a form of constraint. A man sitting on any funding is always a bit kept. ${ }^{13}$

But he mainly ensured he did not become dependent on his own or foreign communities because he knew the degree of dependency of Wańkowicz and the effect of a termination of a subscription to Kultura by an offended portion of the emigration community. He thus wrote to Aniela Mieczysławska: "Either way I don't give a rat's ass whether someone feels offended or not, since 1939 I have constantly had to make sure not to offend some foreigners, first the French, then the domestic rabble, and now the Americans. Because they give." "I4 In the mentioned letter, full of anger towards the emigrant community, who were not able to support ageing renowned Polish writers, Bobkowski emphasised that it was also the reason why he did not want to take money from the Americans, that thus he could honestly and without being embarrassed write about them well or even with admiration.

Bobkowski's vitalism was yet another reason why writing was not amongst his main pursuits. Also in that sense he was not a professional writer, i.e. writing for him was the most important thing without which he would had not been able to live: "For me, art and literature are one thing, and life, munchies, wonderful life, excellent life most of all. For me life itself is the greatest of all arts, and the thing most worth every effort." ${ }^{15} \mathrm{He}$ was completely devoid of any writer's ambitions; thus his rejection of the offer of membership of the Polish Writers' Union in Exile. ${ }^{16}$ Neither was he tempted by the opportunity for professional writing by landing a job at some periodical: "I must be completely immersed in life, and, in general, I can only write when I am able to stop writing," was his response to an offer of collaboration with the Odrodzenie weekly. ${ }^{17}$ His vitalism, and contempt for exaggerated intellectualism, his almost legendary aversion to any ideas and ideologies, and, in turn, artists favouring art over existence and abstraction over concreteness, caused severe criticism by various writers and intellectuals. In response to the publication of his letters (after his death), he was accused of fascism ${ }^{18}$, etc.

13 Ibid., p. 40.

${ }^{14}$ Ibid., p. 82.

15 Ibid., p. 114.

${ }^{16}$ A. Bobkowski, Listy do Tymona Terleckiego 1956-1961, N. Taylor-Terlecka (ed.), Biblioteka „Więzi”, Warsaw 2006, p. 69.

${ }^{17}$ A letter of 1947 to his mother; as cited in "Wstęp" by A.S. Kowalczyk, op. cit., p. 34 (this letter as well can be found in the Archive of the Maisons-Laffitte Literary Institute, and it was not included in the collection of letters he exchanged with his mother: A. Bobkowski, Listy z Gwatemali...).

${ }^{18}$ Such suggestions can be found in, e.g. Miłosz's remarks (Cz. Miłosz, "Uwagi do uwag Gombrowicza", Kultura 1962, issue 12, p. 124; as cited in: K. Ćwikliński, "Furor scribendii albo O pamfletowym charakterze listów Andrzeja Bobkowskiego" in: A. Bobkowski, Listy do różnych adresatów, K. Ćwikliński (ed.), Arcana, Krakow 2013, pp. 7-8. 


\section{Europe corroded with totalitarianism}

One of the major reasons for leaving France was the lack of freedom, the decline of the former republican spirit. The current state of things was tragic: "this whole Europe is utter decay," ${ }^{19}$ Bobkowski summed up everything shortly, while in other instances he offered more precise arguments, e.g. mocking the intellectual influence of the left in the economy.

I have returned to my professional focus: economics. I'm currently studying a collection of articles by all the famous economists entitled L'économie dirigée en regime collectiviste. In the meantime, we are experiencing its outcomes first-hand, ${ }^{20}$

Bobkowski told his mother in February 1946. Descriptions of the results of implementing the elements of socialist economics by the socialist-leaning French governments can be found in his notes entitled $Z$ dziennika podróży. Why did he like South America, and more precisely his new motherland, so much? Because, due to the US intervention, collectivism was not victorious there, and because it lacked an omnipotent state. Unlike in France where at every turn the citizens are monitored, in Guatemala people live without constant supervision:

When I was leaving Europe I swore to myself that I will not stand in a line, that I will not elbow my way, and that if I died, it would not be in a crowd nor holding social insurance. Here, when there are more people on the bus, I never push forward - I wait. I shut my Guatemalan ID card in a steel box, I tossed away the key, and for the past three years I have been living without a single piece of paper on me. ${ }^{21}$

The true dramatic tone of that confession is revealed to a reader when one realises that the author of the letter described in it the state of things in December 1951. The lack of the need to stand in lines, and most of all the ability to move around without a passport or an ID as a proof of freedom was referred to in the letters to Mieczysławska at least thrice during the years of their contact by mail; in 1960 Bobkowski wrote that throughout the 12 years he spent in Guatemala no one had ever required him to present his papers. ${ }^{22}$ Bobkowski's beloved France in particular became in his eyes a semi-totalitarian country of idlers who traded their personal freedom for a social package, while the entire Marshall Plan was a mistake because it supported a nationalised and inefficient economy:

\footnotetext{
${ }^{19}$ Andrzej Bobkowski-Aniela Mieczysławska..., p. 54.

${ }^{20}$ A. Bobkowski, Listy z Gwatemali..., p. 18.

${ }^{21}$ Ibid., p. 47.

${ }^{22}$ Ibid., pp. 158 and 164.
} 
To pump millions into the nationalised production wastefulness of France is truly starting to verge on a lack of common sense. And to shovel huge sums to make sure everyone there kindly grins at the Americans. Work for them, fight for them - everything only because that's where those cathedrals and some paintings are. Screw them! $!^{23}$

He expressed a similar attitude towards the idea of emigre Poles to pressure the Americans to include Poland in the Marshall Plan as well. Why? Because the financing of a "surrealist economy of semi-intelligent doctrinaires" 24 is an idiocy, not "Poland's raison d'être." At this point, one should note that it was the opinion of a person who studied economics, not just a political opponent of communism. His letters to his mother include an argument against the core of the socialist doctrine, which did not take human nature into consideration:

I'm getting slightly dizzy reading those domestic periodicals. It is all pure surrealism what is going on in our country. How can anyone seeing at every turn proof of the utter uselessness, the total failure of the system known as socialism, discuss at the same time its superiority in relation to other systems, and believe that everything can be different in it. So, the Catholic Church has not produced more than one saint a year and is somewhere short of two thousand of them, but those great theoreticians of Marxism would like to manufacture saints by their millions, people to stop stealing, start working efficiently, to be more social, etc. That is terrifying because it comes dangerously close to a mental asylum. In THIS system people HAVE TO steal, people have to be egoists and devils because this system solves nothing and it never will. ${ }^{25}$

Further, somewhat by the way, he remarked that 40 years of communism in Russia had proved the exceptional richness of the country and... the constant help of the "declining capitalism", which prevented the Soviet economy from dying a natural death. That opinion was expressed in 1957, i.e. many years before the downfall of the USSR. Bobkowski believed that bribery, abuses of power, and stealing constituted the core of the system, which is why he was amused by the "combat bribery" projects, of which he read in the PRL press. ${ }^{26}$

\footnotetext{
${ }^{23}$ Ibid., p. 55. A similar remark in: A. Bobkowski, Listy do Jerzego Turowicza..., p. 45.

${ }^{24}$ Andrzej Bobkowski-Aniela Mieczysławska.., p. 107.

${ }^{25}$ A. Bobkowski, Listy z Gwatemali..., pp. 208-209.

${ }^{26}$ Ibid., p. 211.
} 


\section{Growing into Guatemala}

As I have already mentioned, the writer's idée fixe of his independence and freedom led to a change from the status of a political exile to the situation of an economic migrant. That occurred not by accident, but through an intended strategy. His vitality or love for normal life (whatever that could mean exactly) also inclined him to become rooted in the local community. That was evident not only at a time when Guatemala was sliding towards communism and Bobkowski was ready to wield a gun to fend off the armed workers' guard plundering wealthier houses ${ }^{27}$, but he also indicated his fascination for his new-found motherland in his letters. When young people from Poland asked him about his emotional conflict using the typical image of an emigre's torn heart, he responded ruthlessly: "not to rave echoing the three bards [...] because my body and heart are in Guatemala, and only my head is a bit in Poland." ${ }^{28} \mathrm{He}$ wrote similarly in a letter to Jerzy Turowicz, shortly before he died: "Today I understand that you can love some foreign land, and without any detriment to your soul you can have two motherlands." ${ }^{29}$

His letters to various addressees (and Bobkowski was an avid letter writer), and also his excellent report entitled $Z$ notatek modelarza, are full of praise for Central America and the United States. There can be no doubt that the author not only accepted his fellow citizens, and he was fascinated with the American mentality, but also that he considered the great continent discovered by Columbus as a wonderland, if not a paradise. Obviously, even paradise, as we know, was penetrated by a snake, so the mental and moral shortcomings of the descendants of conquistadors were viewed with understanding yet without immediate remission, particularly when it applied to assiduity (an objection rather characteristic for the mentality of a writer who was a workaholic). ${ }^{30}$ Without going into detail,

27 “The recent events here were very interesting. I would have so much to tell you. I still sleep with my Colt by my bed, while two nights before in a bamboo forest by my house they were encircling two communists for an hour, and sprayed machine gun fire, just like I am doing now on my typewriter. But they overcame them. I literally feel now more free and happier than after the liberation of Paris. That was already a tight knot, it smelled of American Korea or Indochina" (Andrzej Bobkowski-Aniela Mieczysławska..., p. 60). A similar description in: Z dziennika modelarza.

${ }_{28}$ Andrzej Bobkowski - Aniela Mieczysławska..., p. 107.

${ }^{29}$ A. Bobkowski, Listy do Jerzego Turowicza..., p. 108. That statement has been disputed by some researchers, e.g. Michał Kopczyk wrote sternly: "Guatemala which he chose as his final destination, and the final stage in a series of his life's ruptures, had never become his motherland, it had never gained the status of the personal centre of his world" (M. Kopczyk, Obecność innego. Studia z literatury współczesnej, Wydawnictwo Naukowe Akademii Techniczno-Humanistycznej, Bielsko-Biała 2013, p. 41).

${ }^{30}$ A. Bobkowski, “Z notatnika modelarza” in: idem, Z dziennika podróży, Biblioteka „Więzi”, Warsaw 2013, pp. 143-144. 
let us conclude emphatically that when compared to the old arrogant Europe, the western hemisphere proved excellent and was worthy of fervent love.

Regardless of how much Bobkowski was posing in his letters when he swore he did not miss Poland, that in Guatemala he had become financially successful, or that he valued life more than the fate and prestige of a writer, the issue of economic independence seems the most important, and was treated with mortal seriousness. A proof of that was his rejection of the offers to relocate to New York or Munich. In the case of the former, the temptation came from Kazimierz Wierzyński, and it included pay of 600 dollars, while in the case of the latter it included a well-paid job in the Free Europe.

While a return to Europe seemed less attractive due to the writer's disappointment in his home continent, the offer to live in the United States he admired so much could have been fascinating for him. Why, then, did he refuse, and his closest friends could hardly understand his attitude? In his letters to his mother, he clearly explained his position: "I had to explain to him [Wierzyński] at length that you cannot reject easily the freedom and independence for which you fought so hard." ${ }^{31}$ As he rejected the offer to work at Radio Free Europe, he shared with his mother his observations regarding the lack of understanding for his position: "I am increasingly terrified in realising that people no longer understand what it means when I say that 'I want to be free.". 32 He reminded her how important personal independence, gained with great effort, was for him: "And between you and me, I am more proud of those ten years 'of not giving in' and of this tiny shop than of all of my scribblings." 33

Though the final two sentences one ought to consider as a rhetorical device as, contrary to what he stated, Bobkowski admired a writer's fame, it would be difficult to ignore the pride in the achieved economic success, and the acquisition of financial independence. His letters to his mother led to yet another trace of his love for the new country of residence: his fascination with the nature in Guatemala. But that is another issue.

\section{Bourgeois virtues}

Freedom understood as economic independence was an idea which Andrzej Bobkowski justified in different ways, and the range of his arguments was not small. One of those was the typical anti-communist attitude. Communism for

\footnotetext{
${ }^{31}$ A. Bobkowski, Listy z Gwatemali..., p. 214.

${ }^{32}$ Ibid., p. 214.

${ }^{33}$ Ibid., p. 215.
} 
the author of Coco de Oro had two disgusting intrinsic dimensions: the politicalpolice dependency which led to moral decay, and the economic quality of slavery. Both elements of the system amplified each other. ${ }^{34}$

One of his initial letters to Turowicz includes a mention of the joy resulting from the fact that he "shook off" his previous life in Europe, and, at the same time, that some people did not understand that fact. Among those he included Jarosław Iwaszkiewicz, who condoled him: "And to think that such a person like yourself has to carve some pinwheels." When quoting the sentence to Turowicz, Bobkowski reported his biting response: "I'd rather carve this than pretend to be an idiot." "35 [The Polish "strugać" (carve, e.g. in wood) can be used in a colloquial phrase "strugać głupka" which means "pretend to be an idiot"] That statement reveals its dramatic nature when one considers how much young Bobkowski admired Iwaszkiewicz. ${ }^{36}$

Yet communism for Bobkowski was merely an extreme case. It was the old Europe that proved unworthy of its identity, and that was why the writer sought happiness in various corners of the world. He paid for it with a lot of effort, and considerable sacrifice, but he knew the price, and did not hesitate to pay it. I believe he expressed it most poignantly in a letter to his uncle of 4 January 1940, i.e. only a few months prior to arriving in Guatemala:

\section{Dear Beloved Uncle!}

It has been six months since I last wrote to you. It has been that long because I lacked both the time and money. That "miserable" 36 cents it costs to send the lightest letter by air mail for us means 5 pounds of sugar or 36 buns, or 4 pounds of potatoes, or 3 pounds of rice, or 3 packs of good cigarettes, or a pound of the best coffee, or a basket of vegetables and fruit, or many more things. Unfortunately, our wages have been such that even 5 cents are a major position, let alone 36 . So do not be angry with me. We have limited ourselves to the most necessary letters; I to my mum, Basia to

${ }^{34}$ In that respect, his remarks regarding the stages of implementing communism in Guatemala are interesting (A. Bobkowski, Z notatnika modelarza, pp. 142-172.).

${ }^{35}$ A. Bobkowski, Listy do Jerzego Turowicza, p. 48.

${ }^{36}$ A fundamental change occurred after the Szczecin Congress of 1949 during which the socalled Socialist realism was announced. In a letter to Giedroyc, he wrote: "Iwaszkiewicz's a total cunt-at least from what I'm getting from Tygodnik Powszechny. I haven't written to him in eighteen months. Last Christmas, I sent him a card with best wishes, but he did not reply. Probably for the best." (J. Giedroyc, A. Bobkowski, Listy..., p. 180). He thus responded to Iwaszkiewicz: "Do not pity me. What am I supposed to do? Write? I know I'll never write anything grand. Do you think that sitting in some office would have been better? Yuck - I hate offices. I am, the emblem of Guatemala - their bird, quetzal. There are only stuffed specimens because live ones held in a cage die within days. And I'm not keen on kicking the bucket, and being stuffed so that I could be viewed” (A. Bobkowski, „Tobie zapisuje Europe”. Listy do Jarostawa Iwaszkiewicza, Jan Zieliński (ed.), Biblioteka „Więzi”, Warsaw 2009, p. 75.). 
her mum and to Jaś in Paris, however rare it would be. But we still haven't regretted a thing. On the contrary. Ever occupied, tired, not able to afford anything extra, we congratulate each other on that decision almost every evening. What can I tell you? Freedom is what I value the most, and recently even in Paris I had begun to feel like in a cage. In fact, I won't go into more detail because you might be able to read what I think about it in one of the coming issues of Kultura. ${ }^{37}$

His high praise of personal independence, which, of course, is not a free condition, was written in a social situation when the community of Polish political emigrants applied censorship in relation to the Paris-based Kultura, thus punishing it for disloyal articles, including Bobkowski's texts. The sales of the periodical were discontinued by emigrant vendors in London, which outraged the writer, who compared the situation to Bierut's Poland. Yet according to Bobkowski, communism was only a special case of a consent for political slavery, of which he also accused the Western society. That was one of the arguments in favour of his departure. In the previously mentioned letter to his uncle, he wrote:

Europe mainly stands for its people. And - what a pity - their quality has been deteriorating at a disquieting pace. Europeans are turning into pacotilles, pillocks, losing all the qualities which once determined their superiority: entrepreneurship, drive for reasonable risk, the ability to apply individual judgement, and sensible defiance. On the contrary: they have become obedient to the State and foreign States. Today, they stand patiently in lines, carefully fill out dozens of forms, and masturbate with passive criticism and intellect as a substitute for life. ${ }^{38}$

The most derisive passages in that description applied to France, once the symbol of civic rights, revolutionary pride, and... assiduity. Bobkowski's shattered faith in the France of old was described probably the most emphatically at the level of the work ethos:

one of my labourer friends, an Italian, became naturalised. He went to the foreman to inform him about it. The foreman congratulated him, and said: "I hope that even

${ }^{37}$ A. Bobkowski, Listy do Aleksandra Bobkowskiego 1940-1961, J. Podolska (ed.), Biblioteka „Więzi”, Warsaw 2013, p. 46-47. Bobkowski often made detailed remarks about the cost of living, sometimes in the context of whether he could afford something, e.g. sending a letter. He similarly justified his limited correspondence with Iwaszkiewicz: "I will have to fit on this single page because each gram of a letter costs something, and we are still not earning anything. Here, not only 36 cents (price of a letter), but even a mere 5 cents is a sum which can buy you many things" (A. Bobkowski, „Tobie zapisuje Europe”, p. 63).

${ }^{38}$ A. Bobkowski, "Na tyłach" in: idem, Coco de Oro, Instytut Literacki Kultura - Instytut Książki, Paris-Krakow 2015, p. 75. 
though you are French, you will continue to work like an Italian." And he said it absolutely seriously. That encapsulates everything, the entire France. ${ }^{39}$

Also not by accident one of Bobkowski's cardinal charges against Europe (with France being its symbol) was contempt for labour and creative technical inventiveness. Bobkowski considered that a betrayal of the civilisational attitude of the old Europe, and juxtaposed it with the attitude of Americans. As always in his writings, the charge was formulated in a polemical manner, and based on a specific example:

We mock Americans that they are stupid, that they cannot understand us, etc. I can't blame them. Ask yourself whether the people who eradicated mosquitoes from the entire zone of the Panama Canal can understand people who could not exterminate those insects even in Juan les Pins, and, at the same time, take such great pride in their culture? ${ }^{40}$

Having thus set the background, he continued to praise the benefits of air conditioning, or the ability to sleep with opened windows without a mosquito net since they had dealt with that infestation. The quoted letter indicates not only the way of viewing the world based on the criteria of the approach towards civilisation, with particular consideration for technical advances and thriftiness, but also says much about the writer's complex self-creative game, where in evaluating his correspondents, he adjusted the roles he played to specific people, yet retained certain constant features of the image he was building. According to Michał Kopczyk:

Being aware of the significance of the game, and the rules that govern it, Bobkowski used the opportunity fighting for his image as a writer, his importance, creating himself from scratch, forging his fate as an emigre settled in a distant land into a situation of a fulfilled man, who, at the same time, was aware of his significance, and his place in the world. Bobkowski fulfilled that strategy both in his correspondence with grand and prominent figures contemporary to him, and with those less known. ${ }^{41}$

It would be difficult to deny the self-creative need in letter writing, particularly in the case of the sense of manly brawn or the incessant emphasising of his - actually limited - success; yet it did not apply much to $Z$ dziennika modelarza, mainly to that part of the journal which included his praises of American capital-

\footnotetext{
${ }^{39}$ A. Bobkowski, „Tobie zapisuję Europę”, p. 32.

${ }^{40}$ Ibid., p. 65.

${ }^{41}$ M. Kopczyk, Obecność innego. Studia z literatury współczesnej, Bielsko-Biała 2013, p. 37.
} 
ism, more specifically: his fascination with the business culture. The praises were absolutely unbiased. They applied not only to the opposition towards the fear that the technical civilisation "is killing poetry", because, according to the writer, it is not technology that threatens literature, rather the coldness of the heart. ${ }^{42}$

Bobkowski mainly found pleasure in describing how hard-working, professional, and mindful of the customer small companies, often family concerns were, those which cherished high product quality, and did not succumb to the temptation of easy, though one-time only, profit, rather the contrary: focussed on long-term and honest business based on mutual trust. That was what business relations with a company from New York ${ }^{43}$ and from Chicago ${ }^{44}$ looked like. Yet Bobkowski was probably most impressed with two things: the limitation of redtape, and free business advice. Americans were hard-pressed to adjust to Guatemalan forms for imported goods. But they perfectly understood the essence of their trade activities, and suggested to their partner that he should ensure service for his products, which would make him unrivalled in his area.

His US observations enabled Bobkowski the economist to formulate one of the most interesting opinions on communism. It is exceptionally incisive, and its accuracy is astonishing considering the times, when it seemed that the system possessed an intellectual edge: "Despite all its pretences and theories of dynamism, communism dreams of halting development, of petrification; its dream is to count the spokes in an immobile wheel." ${ }^{45}$ That acute metaphor by an avid cyclist came to being based on his observations of the dynamism of American entrepreneurship. At the same time, it clearly vindicated the decision not only not to return to post-WWII Poland, but not even to Europe.

\section{Bibliography}

\section{Subject bibliography}

Andrzej Bobkowski - Aniela Mieczysławska. Listy 1951-1961, Biblioteka "Więzi”, Warsaw 2010.

“Biografia wielkiego Kosmopolaka”, Kultura 1960, issue 9/155; http://static.kulturaparyska.com/ attachments/cb/b0/4389fdd1ef03ab9dd13faf07db8cccde93451e83.pdf\#page=11 (accessed on: 28.11.2015).

Bobkowski Andrzej, Coco de Oro, Instytut Literacki Kultura - Instytut Książki, Paris-Krakow 2015.

Bobkowski Andrzej, Listy do Aleksandra Bobkowskiego 1940-1961, J. Podolska (ed.), Biblioteka "Więzi", Warsaw 2013.

Bobkowski Andrzej, Listy do Jerzego Turowicza 1947-1960, M. Urbanowski (ed.), Biblioteka "Więzi", Warsaw 2013.

Bobkowski Andrzej, Listy do różnych adresatów, K. Ćwikliński (ed.), Arcana, Krakow 2013.

\footnotetext{
${ }^{42}$ A. Bobkowski, Z notatnika modelarza, p. 179.

${ }^{43}$ Ibid., pp. 181-182.

${ }^{44}$ Ibid., pp. 191-193.

${ }^{45}$ A. Bobkowski, Z notatnika modelarza, p. 194.
} 
Bobkowski Andrzej, Listy do Tymona Terleckiego 1956-1961, N. Taylor-Terlecka (ed.), Biblioteka "Więzi", Warsaw 2006.

Bobkowski Andrzej, Listy z Gwatemali do matki, E. Jurczyszyn (ed.), Twój Styl, Warsaw 2008).

Bobkowski Andrzej, Szkice piórkiem (Francja 1940-1944), Kontra, London 1985.

Bobkowski Andrzej, „Tobie zapisuje Europe”. Listy do Jarosława Iwaszkiewicza, Jan Zieliński (ed.), Biblioteka "Więzi", Warsaw 2009.

Bobkowski Andrzej, Z dziennika podróży, Biblioteka „Więzi”, Warsaw 2013.

Giedroyc Jerzy, Andrzej Bobkowski, Listy 1946-1961, Czytelnik, Warsaw 1997.

\section{Object bibliography}

Andrzej Bobkowski wielokrotnie, K. Ćwikliński, A.S. Kowalczyk, M. Urbanowski (eds.), Biblioteka „Więzi”, Warsaw 2014.

Kopczyk Michał, Obecność innego. Studia z literatury współczesnej, Wydawnictwo Naukowe Akademii Techniczno-Humanistycznej, Bielsko-Biała 2013.

Nowak Maciej, Na tuku elektrycznym. O pisaniu Andrzeja Bobkowskiego, Biblioteka „Więzi”, Warsaw 2014.

Ćwikliński Krzysztof, “Andrzeja Bobkowskiego ars epistolandi”, Odra 1992, issue 6, pp. 19-20.

Dybciak Krzysztof, “Sztuka bycia wolnym człowiekiem”, Tygodnik Solidarność 1996, issue 23, p. 17.

Stabro Stanisław, "Andrzej Bobkowski - biografia symboliczna”, Ruch Literacki 1993, col. 4, pp. 375-389.

Stabro Stanisław, "Europa odrzucona”, Twórczość 1991, issue 9, pp. 74-87.

Urbanowski Maciej, "Krzyk chuligana”, Arcana 1995, issue 4, pp. 142-145.

Urbanowski Maciej, "Szczęście pod wulkanem”, Nowe Państwo 2001, issue 24, pp. 36-37.

Zagańczyk Marek, “Najpierw żyć”, Kultura Niezależna 1990, issue 59, pp. 79-84.

Zieliński Jan, "Ode mnie przynajmniej listy coś są warte (o listach Andrzeja Bobkowskiego do rodziny)", Twórczość 1984, issue 8, p. 87.

Zieliński Jan, “Wielki Spokój”, Teksty Drugie 1991, issue 1-2, pp. 96-108.

Józef Maria Ruszar

\section{Freedom and possession in the letters of Andrzej Bobkowski}

\section{(Summary)}

For Bobkowski, to maintain personal freedom based on material independence achieved through his own work was a fundamental existential issue. Freedom and financial independence were: a declaration, a life's motto and an economic programme. The writer's concept was, eventually, reduced to a change of his status as a political exile to the situation of an economic migrant who also supported Poland's freedom.

Keywords: Andrzej Bobkowski, The New Economic Criticism, Freedom 